\title{
DINAMIKA HASIL TANGKAPAN BARONANG (Siganus sp.) PADA RUMPON HIDUP SECARA SPASIAL-TEMPORAL DI PESISIR ULOULO KABUPATEN LUWU
}

\author{
Dynamics of Siganus sp., Catch in Bio- FADs in Spatial and Temporal in Water Coastal \\ Uloulo Luwu District
}

Oleh:

\begin{abstract}
Suardi $1^{*}$, Budy Wiryawan², Am Azbas Taurusman ${ }^{3}$, Joko Santoso ${ }^{4}$, Mochammad Riyanto ${ }^{5}$
1 Program Studi akuakultur, Fakultas Perikanan, Universitas Andi Djemma Palopo.suardi_perikanan@yahoo.co.id 2 Departemen Pemanfaatan Sumberdaya Perikanan Fakultas Perikanan dan Ilmu Kelautan Institut Pertanian Bogor. bud@psp_ipb.org

${ }^{3}$ Departemen Pemanfaatan Sumberdaya Perikanan Fakultas Perikanan dan Ilmu Kelautan Institut Pertanian Bogor. azbastm@yahoo.com

4 Departemen Pemanfaatan Sumberdaya Perikanan Fakultas Perikanan dan Ilmu Kelautan Institut Pertanian Bogor. joko2209@yahoo.com

${ }^{5}$ Departemen Pemanfaatan Sumberdaya Perikanan Fakultas Perikanan dan Ilmu Kelautan Institut Pertanian Bogor. mh_ryn@yahoo.com
\end{abstract}

${ }^{*}$ Korespondensi: suardi_perikanan@yahoo.co.id

Diterima: 22 September 2017; Disetujui: 14 Mei 2019

\begin{abstract}
Biological-Fish Aggregation Devices (Bio FADs) is FADs which designed used seaweed as an attractor. Bio FADs in this study were made using two species of seaweed i.e Eucheuma cottonii, called cottonii FADs (FC) and Gracilaria sp. called gracilaria FADs (FG). The purpose of this study was to analyze the dynamics of Siganus sp catch around Bio FADs based on species, abundance, and ecological characteristics spatially and temporally. The research was conducted in Uloulo coastal waters of Luwu district from October 2014 to August 2015. Fish samples were collected by using scoop net on both types of FADs which were installed in three different habitats as observation stations. The Shannon-Wienner $\left(H^{\prime}\right)$ diversity index is relatively moderate in spatially and temporally. ANOSIM shows that the abundance of fish catches between habitats is significantly different $(R=0,268 ; p=0,001)$. River estuary habitat has the highest abundance of catches which is about $14.77 \mathrm{ind} / \mathrm{m}^{2}$. Furthermore, the abundance of catches between monsoon was significantly different $(R=0,110 ; p=0,001)$. The highest abundance of fish catches in the west monsoon (WM) is about 20,67 ind $/ \mathrm{m}^{2}$. SIMPER analysis shows that Siganus canaliculatus is the main species based on habitat and season. The contribution of Siganus canaliculatus is quite high in seagrass habitat which is about $96.38 \%$.
\end{abstract}

Keywords: Bio-FADs, dynamics of catch, Siganus sp.

\section{ABSTRAK}

Rumpon hidup atau Biological-Fish Aggregation Devices adalah rumpon yang didesain menggunakan rumput laut sebagai atraktor. Rumpon hidup pada penelitian ini dibuat dengan menggunakan rumput laut jenis Eucheuma cottonii sehingga disebut rumpon cottonii( $R C)$ dan Gracillaria sp atau rumpon gracillaria (RG). Tujuan penelitian ini adalah menganalisis dinamika 
hasil tangkapan ikan baronang (Siganus sp.) di sekitar rumpon hidup berdasarkan jenis, kelimpahan, dan karakteristik ekologis secara spasial dan temporal. Penelitian ini dilaksanakan di perairan pesisir Uloulo Kabupaten Luwu dari bulan Oktober 2014 sampai Agustus 2015. Sampel ikan dikumpulkan dengan menggunakan serok pada kedua jenis rumpon yang dipasang di tiga habitat yang berbeda sebagai stasiun pengamatan. Indeks diversitas Shannon-Wienner $(H)$ secara spasial dan temporal relatif moderat. Hasil ANOSIM menunjukkan bahwa kelimpahan hasil tangkapan ikan antar habitat berbeda sangat nyata, $(R=0,268 ; p=0,001)$. Habitat muara sungai memiliki kelimpahan hasil tangkapan tertinggi yaitu $14,77 \mathrm{ind} / \mathrm{m}^{2}$. Selanjutnya kelimpahan hasil tangkapan berdasarkan musim berbeda nyata $(R=0,110 ; \mathrm{p}=$ 0,001 ). Kelimpahan hasil tangkapan ikan tertinggi pada musim barat (MB) yaitu $20,67 \mathrm{ind} / \mathrm{m}^{2}$ .Analisis SIMPER menunjukkan bahwa Siganus canaliculatus sebagai spesies utama berdasarkan habitat dan musim. Kontsribusi Siganus canaliculatus cukup tinggi pada habitat padang lamun yaitu sebesar $96,34 \%$.

Kata kunci: rumpon hidup, dinamika hasil tangkapan, Siganus sp.

\section{PENDAHULUAN}

Perairan pesisir Kabupaten Luwu terletak di zona utara Teluk Bone dalam pembagian zona dalam rangka rencana tataruang pesisir dan pulau-pulau kecil kawasan Teluk Bone, Provinsi Sulawesi Selatan. Wilayah pesisir Kabupaten Luwu relatif subur karena daerah pesisirnya ditemukan berbagai ekosistem diantaranya estuaria, mangrove, padang lamun dan terumbu karang. Ekosistem ini memiliki fungsi yang sangat vital karena menjadi area pemijahan, berlindung dan mencari makan berbagai jenis ikan (Nybakken 1988).

Salah satu famili ikan yang dominan ditemukan pada empat ekosistem tersebut adalah Siganidae atau ikan baronang. Jumlah jenis ikan baronang yang ditemukan di Indonesia ada 12 spesies (Nontji 1987) dan 7 spesies (Sudradjat 2009). Baronang menyebar mulai dari wilayah Indo-Pasifik Barat, dari Teluk Arabia sampai wilayah barat Australia dan ditemukan pula di Hongkong dan Taiwan (AI-Marzouqi 2013). Penyebaran ikan baronang di Indonesia cukup luas akan tetapi penyebaran spesies sangat terbatas (Sewajo et al. 1981).

Populasi ikan baronang mengalami peningkatan seiring dengan bertambahnya area budidaya rumput laut. Rumput laut yang dibudidayakan nelayan menjadi habitat alternatif juvenil (yuana) ikan baronang. Namun muncul masalah untuk ikan-ikan muda (juvenil) yaitu mengalami kematian secara massal disaat nelayan memanen rumput lautnya dan ikan baronang dewasa memangsa rumput laut yang dibudidayakan nelayan. Sementara itu, jika juvenil dan baronang dewasa ini dikelola dengan baik akan mendatangkan keuntungan secara ekologis dan ekonomis (Suardi et al. 2016a).
Mengumpulkan juvenil dan baronang Siganus sp. dewasa di area budidaya rumput laut yang luas membutuhkan teknologi yang dianggap efektif untuk memikat juvenil tersebut. Salah satu teknologi yang dianggap efektif adalah teknologi rumpon. Rumpon yang digunakan adalah rumpon hidup atau Biological-Fish Aggregation Divices (Bio-FAD) yang dirancang secara khusus dengan menggunakan rumput laut sebagai atraktornya. Penggunaan rumput laut sebagai atraktor untuk tujuan memikat juvenil ikan baronang sebagaimana tertariknya ikan-ikan juwana pada rumput laut yang dibudidayakan nelayan. Rumpon adalah alat bantu penangkapan ikan yang multi fungsi (Subani 1986); dan perbedaan atraktor pada rumpon turut berpengaruh terhadap daya pikat terhadap ikan pelagis (Yusfiandayani et al. 2010).

Informasi mengenai daya pikat rumpon hidup terhadap juvenil ikan baronang Siganus sp., masih sangat terbatas, karena penelitian mengenai penangkapan juvenil baronang menggunakan teknologi rumpon hidup baru pertama kali dilakukan (Suardi et al. 2016a), sehingga masih diperlukan penelitian mengenai penggunaan rumpon hidup untuk menganalisis dinamika hasil tangkapan ikan baronang secara spasial dan temporal. Tujuan penelitian ini adalah menganalisis dinamika hasil tangkapan ikan baronang (Siganus sp.) berdasarkan jenis, kelimpahan, dan karakteristik ekologis secara spasial dan temporaldi perairan pesisir Uloulo Kabupaten Luwu.

\section{METODE}

Penelitian ini dilaksanakan di perairan pesisir Uloulo Teluk Bone, Kabupaten Luwu (Gambar 1) dan waktu penelitian dilaksanakan 
selama 12 bulan (Oktober 2014 - September 2015) yang dibagi dalam 4 musim yaitu musim barat (MB) Oktober - Desember 2014, musim peralihan 2 (MP-2) Januari - Maret 2015 musim timur (MT) April - Juni 2015, dan musim peralihan 1 (MT-1) Juli - September 2015, (Suardi et al. 2016a).

Penelitian ini dibagi dalam 3 lokasi sebagai stasiun pengamatan, sebagaimana yang disajikan pada Tabel 1. Penentuan lokasi menggunakan metode zonasi (segmentasi) dengan mempertimbangkan karakteristik perair- an berdasarkan pada perbedaan tipologi masing-masing stasiun (habitat). Penentuan stasiun (habitat) penelitian sebagai lokasi penempatan rumpon berdasarkan pada asumsi bahwa: (1) sampel ikan baronang yang diperoleh akan mewakili distribusi secara spasial dan temporal, (2) habitat sesuai dengan penyebaran ikan tersebut dan (3) adanya perbedaan parameter fisik dan kimia perairan.

Berdasarkan karakteristik habitat penelitian di atas maka ditetapkan tiga lokasi (habitat) penelitian sebagai berikut:

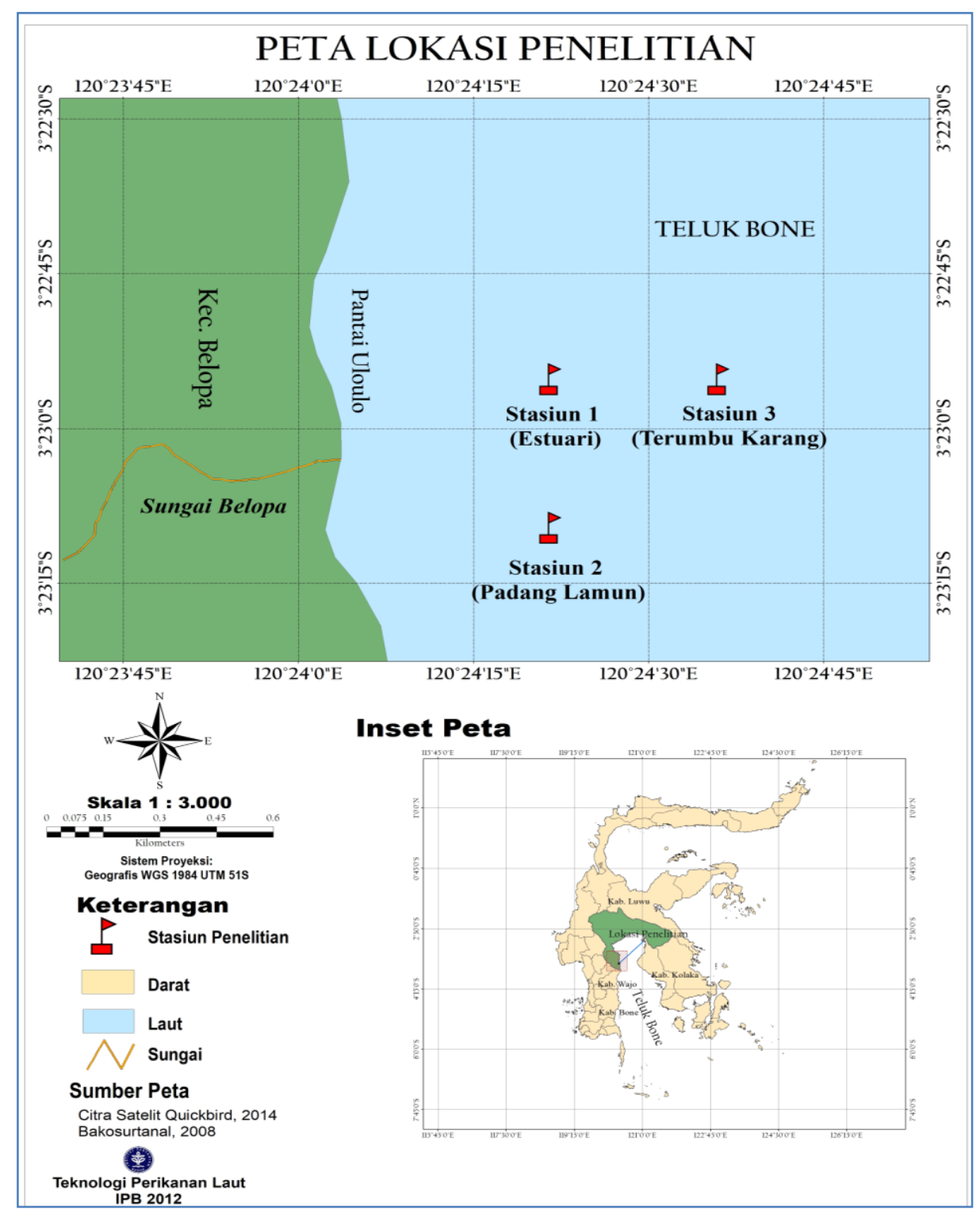

Gambar 1 Lokasi penelitian dan titik sampling mewakili stasiun (habitat) yang berbeda ( Lk.1= muara sungai (Estuary), Lk. 2 = padang lamun (Sea Grass Bed) dan Lk $3=$ terumbu karang (Coral Reef)) 
Tabel 1 Karakteristik lokasi penelitian pada habitat muara sungai (estuaria), padang lamun dan terumbu karang

\begin{tabular}{|c|c|c|c|c|}
\hline \multirow{2}{*}{ No } & \multirow{2}{*}{ Karakteristik } & \multicolumn{3}{|c|}{ Habitat (lokasi) } \\
\hline & & Muara sungai (MS) & Padang lamun (PL) & Terumbu karang(TK) \\
\hline 1 & $\begin{array}{l}\text { Posisi } \\
\text { geografis }\end{array}$ & $\begin{array}{l}\text { E } 120^{\circ} 24^{\prime} 09,304^{\prime \prime}- \\
\text { L } 3^{\circ} 22^{\prime} 37,064^{\prime \prime}\end{array}$ & $\begin{array}{l}\text { E } 120^{\circ} 24^{\prime} 10,447^{\prime \prime} \\
\text { - L } 3^{\circ} 22^{\prime} 56,243^{\prime \prime}\end{array}$ & $\begin{array}{l}\text { E } 120^{\circ} 24^{\prime} 21,20^{\prime \prime}- \\
\text { L } 3^{\circ} 22^{\prime} 36,140^{\prime \prime}\end{array}$ \\
\hline 2 & Kedalaman & $3-10 m$ & $3-10 m$ & $5-15 m$ \\
\hline 3 & $\begin{array}{l}\text { Kekhasan } \\
\text { habitat }\end{array}$ & $\begin{array}{l}\text { Suplai air tawarlangsung dari } \\
\text { sungai,dekat dengan } \\
\text { pemukiman nelayan, } \\
\text { berdekatan dengan jalur } \\
\text { lalulintasnelayan, tingkat } \\
\text { kecerahan rendah, intensitas } \\
\text { pengadukan tinggi,fluktuasi } \\
\text { salinitas tinggia) }\end{array}$ & $\begin{array}{l}\text { Suplai air } \\
\text { tawardari } \\
\text { aratan,ditumbuhi } \\
\text { lamundanmakro } \\
\text { alga, tingkat } \\
\text { kecerahan rendah, } \\
\text { salinitas } 10-25 \%\end{array}$ & $\begin{array}{l}\text { Perairannya jerni, } \\
\text { ditumbuhi makro alga, } \\
\text { arusnya tinggi, } \\
\text { salinitas antara } \\
\left.30-36 \%{ }^{b}\right)\end{array}$ \\
\hline 4 & Substrat & Lumpur dan pasir & Lumpur dan pasir & $\begin{array}{l}\text { Batuan, pasir dan } \\
\text { karang mati }\end{array}$ \\
\hline
\end{tabular}

Rumpon hidup yang digunakan pada penelitian ini adalah rumpon yang menggunakan rumput laut sebagai atraktor. Rumput laut yang digunakan yaitu rumput laut Eucheumacottonii sehingga rumpon ini disebut rumpon cottonii ( $\mathrm{RC}$ ) dan rumput laut Gracillaria sp dan disebut pula sebagai rumpon gracillaria (RG). Kedua rumpon ini terdiri dari $3 \mathrm{RC}$ dan $3 \mathrm{RG}$. Rumpon hidup tersebut dipasang masing-masing 2 unit di 3 stasiun (habitat). Rumpon hidup dipasang di tiga habitat dengan maksud untuk mengetahui dinamika hasil tangkapan ikan baronang secara spasial seperti jenis baronang, kelimpahan, keanekaragaman dan indeks dominan. Selanjutnya untuk sampling atau pengumpulan sampel ikan yang berasosiasi dengan rumpon digunakan alat bantu serok atau scoopnet (bunde: nama lokal). Bahan yang digunakan pada rumpon hidup dan serok (alat bantu sampling ikan) disajikan pada Tabel 2 dan 3, konstuksi rumpon hidup dan serok disajikan pada Gambar 2 dan 3.

Tabel 2 Bahan yang digunakan pada konstruksi rumpon hidup

\begin{tabular}{|c|c|c|c|c|}
\hline No & Komponen & Bahan & Ukuran (panjang/bobot) & Jumlah \\
\hline \multirow[t]{2}{*}{1} & Pelampung & Stryfoam & Lebar : $60 \mathrm{~cm}$ dan tinggi : $45 \mathrm{~cm}$ & 6 unit \\
\hline & & Waring & Mesh zise $0.5 \mathrm{~cm}$ & $12 \mathrm{~m}$ \\
\hline \multirow[t]{2}{*}{2} & Rangka rumpon & Bambu & Panjang : $180 \mathrm{~cm}$ dan lebar : $2 \mathrm{~cm}$ & $36 \mathrm{lbr}$ \\
\hline & & Rotan & Panjang : $160 \mathrm{~cm}$ dan $\varnothing=1,5 \mathrm{~cm}$ & $24 \mathrm{btg}$ \\
\hline \multirow[t]{2}{*}{3} & Atraktor & $\begin{array}{l}\text { Rumput laut } \\
\text { (Eucheuma cottonii) } \\
\text { Rumput laut (Gracillaria }\end{array}$ & $1,4 \mathrm{~kg} / \mathrm{rumpon}$ & $8,4 \mathrm{~kg}$ \\
\hline & & $\begin{array}{l}\text { sp.) } \\
\text { Tali Pelampung (PE) no. }\end{array}$ & $1,4 \mathrm{~kg} /$ rumpon & 8,4 kg \\
\hline \multirow[t]{6}{*}{4} & Tali temali & & 4 m/rumpon & $24 \mathrm{~m}$ \\
\hline & & Tali pemberat (PE) no. 10 & 15 m/rumpon & $90 \mathrm{~m}$ \\
\hline & & $\begin{array}{l}\text { Tali bentangan (PE) no. } 6 \\
\text { Tali perekat rumpon (PE) }\end{array}$ & 24 m/rumpon & $144 \mathrm{~m}$ \\
\hline & & no. 6 & 12 m/rumpon & $72 \mathrm{~m}$ \\
\hline & & Tali paus (PE) no. 2.5 & 15 m/rumpon & $90 \mathrm{~m}$ \\
\hline & & Kawat etenar $\varnothing 1,5 \mathrm{~mm}$ & 5 m/rumpon & $30 \mathrm{~m}$ \\
\hline 5 & Swivel & Besi & 1 unit/rumpon & 6 unit \\
\hline \multirow[t]{2}{*}{6} & Pemberat & Pemberat jangkar & $45 \mathrm{~kg} / \mathrm{rumpon}$ & $270 \mathrm{~kg}$ \\
\hline & & Pemberat rumpon & $2,5 \mathrm{~kg}$ & $15 \mathrm{~kg}$ \\
\hline
\end{tabular}




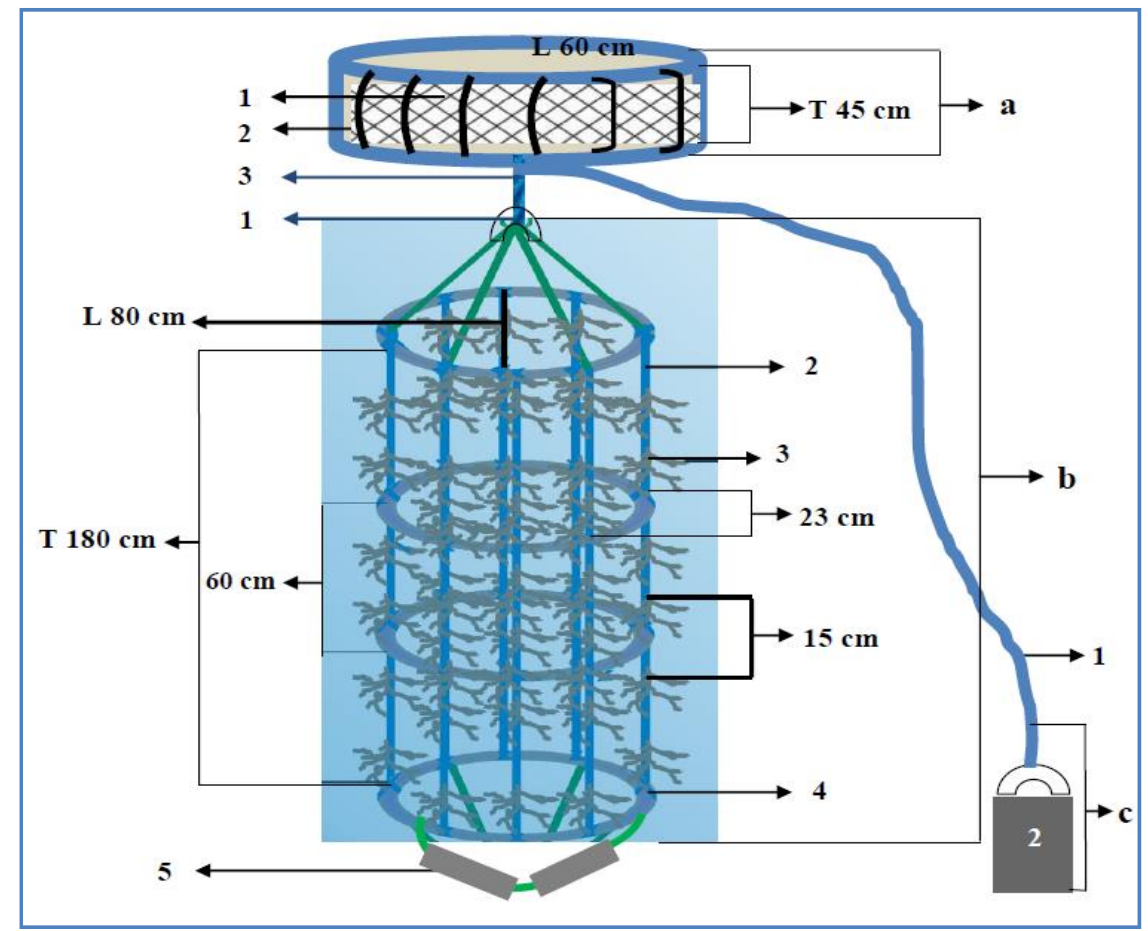

Keterangan:
(a) Pelampung (gabus)
(b) Rumpon
1. kili-kili
1. waring
2. rusuk (bambu)
3. tali pelampung
3. atraktor (rumput laut)
4. lingkaran (rotan)
5. pemberat (coran)

(c) Pemberat

Sumber : Suardi et al. 2016a

1. tali pemberat

2. pemberat utama

Gambar 2 Konstruksi rumpon hidup yang digunakan pada penelitian

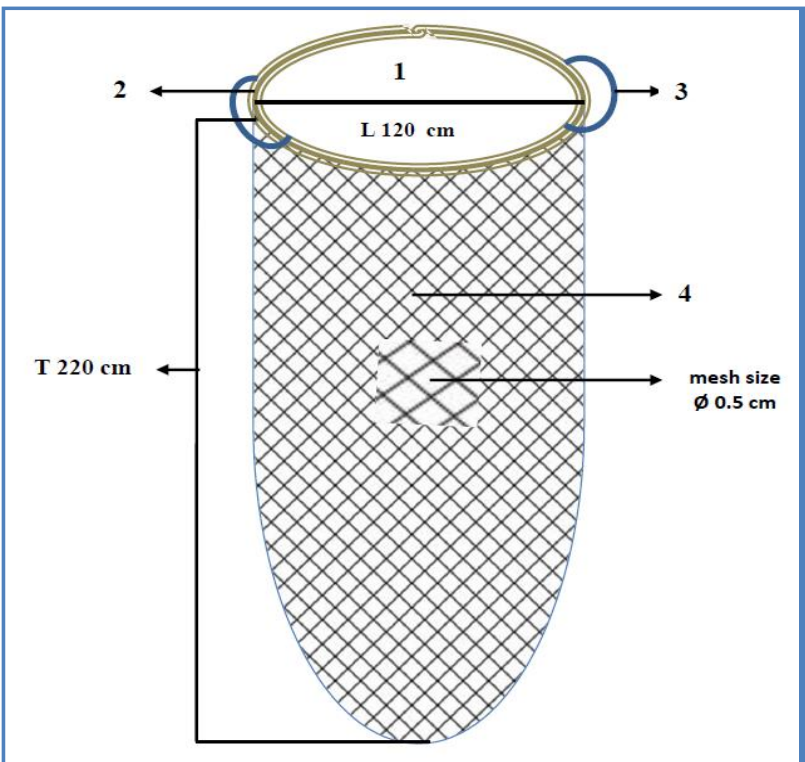

Keterangan:

1. mulut

2. lingkaran mulut (rotan)

3. gagangan (tali nilon PE. no. 10)

4. waring

Sumber : Suardi et al. 2016a

Gambar 3 Konstruksi serok (scoop net) alat yang digunakan untuk mengumpulkan ikan di rumpon 
Tabel 3 Bahan yang digunakan pada konstruksi serok (alat sampling ikan)

\begin{tabular}{rllll}
\hline No & Komponen & Bahan & Ukuran (panjang/bobot) & Jumlah \\
\hline \multirow{2}{1}{1} & Rangka serok & Rotan & Panjang: $160 \mathrm{~cm}$ dan $\varnothing=1,5 \mathrm{~cm}$ & 1 batang \\
& & Waring & Mesh zise $0.5 \mathrm{~cm}$ & $4 \mathrm{~m}$ \\
\multirow{2}{*}{2} & \multirow{2}{*}{ Tali temali } & Tali gagang (PE) no. 10 & $0,5 \mathrm{~m} /$ serok & $0,5 \mathrm{~m}$ \\
& & Kawat etenar & $1 \mathrm{~m} /$ serok & $1 \mathrm{~m}$ \\
\hline
\end{tabular}

Penentuan titik penempatan rumpon di masing-masing lokasi (habitat) dengan pertimbangan karakteristik lokasi seperti: 1) kedalaman air pada surut terendah minimal $2,5 \mathrm{~m}$, 2) aman dari lalulintas perahu nelayan, 3) kecepatan arus 0,4-0,5 dan 4) kecerahan perairan cukup tinggi. Kemudian posisi rumpon hidup dalam kolom perairan berdiri tegak (vertikal), penempatannya sejajar dengan garis pantai, jarak badan rumpon dengan permukaan air 15 $\mathrm{cm}$ dan jarak antar rumpon di setiap stasiun sekitar $25 \mathrm{~m}$.

Sampel ikan baronang dikumpulkan dengan menggunakan alat bantu penangkapan serok seperti yang disajikan pada (Gambar 3), pada masing-masing rumpon hidup yang dipasang di tiga stasiun penelitian. Pengambilan sampel dilakukan sebanyak 4 kali pada setiap habitat dan musim yang berbeda.

Prosedur pengambilan sampel ikan baronang pada rumpon hidup dengan menggunakan serok, baik pada muara sungai, padang lamun dan terumbu karang, melalui beberapa tahapan yaitu: 1) sampling dilakukan oleh dua orang kemudian secara bersamaan menyelam di samping (sisi) rumpon, 2) setelah sampai di ujung bawah rumpon, selanjutnya rumpon dimasukan ke dalam serok dengan cara menyarungi, 3) setelah rumpon benar-benar sudah sepenuhnya berada dalam serok kemudian serok ditarik ke atas perahu bersama dengan rumpon, 4) rumpon digoyang-goyang agar seluruh ikan yang terpikat di rumpon masuk ke serok, 5) serok dilepaskan dari rumpon kemudian ikan yang tertangkap dari rumpon dikumpulkan di wadah, lalu dihitung berdasarkan jenis, jumlah ikan setiap jenis, berdasarkan habitat (spasial) dan musim (temporal).

Data yang diperoleh dari lapangan kemudian dikelompokkan berdasarkan habitat (spasial) dan musim (temporal). Data penelitian ini diolah menggunakan bantuan perangkat lunak (software) PRIMER versi 5.2 (Plymouth Routines In Multivariate Ecological Research) (Taurusman 2011).

Pengukuran struktur komunitas ikan yang berasosiasi dengan rumpon hidup (Bio FAD) dikelompokkan secara spasial (habitat) dan temporal (musim). Hasil tangkapan ikan baro- nang dianalisis berdasarkan jumlah spesies, kelimpahan dan Indeks diversitas. Kemudian untuk menganalisis parameter keaneragaman (diversitas), korelasi antar parameter, karakteristik spesies dan similiritas digunakan statistik multivariate. Secara detail analisis-analisis yang digunakan adalah:

\section{Analisis kelimpahan (A)}

Kelimpahan ikan baronang dikelompokkan berdasarkan spesiesnya. Hasil pengelompokkan dianalisis dengan membandingkan kelimpahan rata-rata ikan baronang secara spasial (habitat) dan temporal (musim). Kelimpahan organisme dalam suatu perairan dapat dinyatakan sebagai jumlah individu per area (Odum 1998) dihitung dengan persamaan:

$A=\frac{X i}{n i}$

Keterangan:

$A=$ kelimpahan individu (ind $\left./ \mathrm{m}^{2}\right)$,

$\mathrm{Xi}=$ jumlah individu dari spesies ke-i,

$\mathrm{ni}=$ jumlah luasan kuadran spesies ke -i ditemukan.

\section{Indeks diversitas (keanekaragaman)}

Pengolahan data indeks keanekaragaman $(H)$, menggunakan formulasi Krebs (1989). Analisis ini terdiri dari jumlah jenis (s) jumlah individu (N), Margalef's species richness (d) kemerataan (Pielou's evenness J'), ShannonWiener's diversity index $(H)$. Perhitungan nilai $H^{\prime}$ didasarkan atas jumlah individu setiap spesies (N) yang tertangkap pada rumpon hidup sebagaimana yang digunakan (Krebs 1989) dalam menentukan nilai $H^{\prime}$, persamaan (2) dan (3) Besarnya indeks keragaman diformulasikan sebagai berikut:

$H^{\prime}=-\sum_{i=1}^{S} P_{i} \log _{2} P_{i}$

$H^{\prime}=-\sum_{i=1}^{S}\left(\frac{n i}{N}\right) \log _{2}\left(\frac{n i}{N}\right)$

Keterangan :

$\mathrm{H}^{\prime}$ = indeks keragaman Shannon-Wiener,

$\mathrm{S}=$ jumlah taksa,

$\mathrm{Pi}=\mathrm{ni} / \mathrm{N}$,

$\mathrm{n}_{\mathrm{i}}=$ jumlah individu jenis ke $\mathrm{i}$,

$\mathrm{N}=$ jumlah total individu. 
$H^{\prime}$ akan maksimum jika semua spesies atau genus menyebar secara homogen, yaitu :

$H^{\prime}$ maks $=\log _{2} s$

\section{Analisis klaster (cluster analysis)}

Analisis klaster dilakukan untuk mengetahui hubungan struktur hasil tangkapan ikan baronang yang berasosiasi dengan rumpon secara spasial dan temporal. Indeks similaritas Bray-Curtis digunakan untuk membuat matrik nilai similaritas antara data-data hasil tangkapan berdasarkan habitat dan musim. Data terlebih dahulu distandarisasi dengan transformasi akar 4 ( $4^{\text {h }}$ - root transformed). Selanjutnya analisis klaster diplotkan dalam bentuk dendogram dan melakukan pengujian statistik.

\section{Analisis similaritas atau analysis of similarities (ANOSIM)}

Analisis similaritas digunakan untuk menguji beda nyata secara statistik kelimpahan hasil tangkapan baronang antara habitat dan musim. ANOSIM adalah suatu analisis non-parametrik seperti analysis of variance (ANOVA), yang dilakukan dengan basis rangking nilai-nilai dalam matrik similaritas (Quinn dan Keough 2002; Taurusman 2011).

Taurusman (2011) merekomendasikan untuk menggunakan ANOSIM untuk menguji hipotesis berbeda antara grup dalam multivariat statistik. Hubungan similaritas berdasarkan perubahan nilai $\mathrm{R}$ menurut persamaan berikut:

$$
\begin{aligned}
& R=\frac{\text { aver. } r b \text {-aver } . r w}{M 2} \\
& M=\frac{n(n-1)}{2} \ldots \ldots \ldots \ldots \ldots
\end{aligned}
$$

Keterangan:

aver. $r b=$ rata-rata rangking similaritas data antara kelompok (group),

aver. $r w$ = rata-rata rangking data yang menyebar merata di dalam kelompok (group) atau dalam suatu habitat, bulan/musim tertentu.

Interpretasi nilai R (Clarke's R) menggambarkan tingkat perbedaan antar kelompok, dengan skala 0 (tidak dapat dibedakan) hingga 1 (semua data dalam kelompok adalah kurang dari rata-rata data antar kelompok).

\section{Similarity percentage (SIMPER)}

Analisis ini digunakan untuk mengetahui spesies kunci (jenis ikan baronang) yang menentukan karakteristik suatu kelompok data (dalam hal ini habitat dan musim), biasanya ditentukan oleh nilai jumlah individu atau bobot yang menyebar secara merata.

\section{HASIL DAN PEMBAHASAN}

\section{Diversitas $(H)$ hasil tangkapan baronang (Siganus sp.) berdasarkan habitat dan musim}

Berdasarkan hasil tangkapan ikan baronang yang berasosiasi pada rumpon hidup yaitu rumpon cottonii (RC) dan rumpon gracillaria ( $R G$ ) yang dipasang di habitat muara sungai, padang lamun dan terumbu karang, telah diperoleh data struktur komunitas ikan baronang seperti jumlah jenis, kelimpahan individu, dan indeks diversitas sebagaimana yang disajikan pada Tabel 4 berikut.

Distribusi spesies ikan baronang yang berasosiasi dengan rumpon hidup pada tiga habitat menunjukkan jumlah spesies yang sama yaitu masing-masing 5 jenis (Tabel 4). Kesamaan jumlah spesies ikan baronang pada rumpon hidup di tiga habitat diduga karena penggunaan atraktor rumput laut pada rumpon hidup untuk memikat ikan baronang sebagai ikan herbivora (Kune 2007; Yusfiandayani et al. 2014, produktivitas tinggi pada rumpon portabel). Simbolon et al. ( 2011) menggunakan rumpon lebih efektif untuk menangkap ikan. Selanjutnya Nevada et al. (2012) menggunakan rumput laut sebagai atraktor untuk menangkap jenis juvenil lobster hijau pasir (Panulirus homorus). Selanjutnya fungsi rumpon sebagai tempat berlindung, asuhan, mencari makan dan memijah berbagai jenis ikan (Dempster T. 2003). Samples dan Sproul (1985) menyatakan bahwa tertariknya ikan di sekitar rumpon disebabkan karena beberapa faktor antara lain: 1) rumpon sebagai tempat berteduh (shading place) untuk beberapa jenis ikan tertentu; 2) rumpon sebagai tempat mencari makan (feeding ground), 3) rumpon sebagai substrat untuk menempatkan telur ,4) rumpon sebagai tempat berlindung dari serangan ikan predator dan 5) rumpon sebagai tempat titik acuan navigasi (meeting point) bagi ikan-ikan yang beruaya.

Kelimpahan hasil tangkapan ikan baronang pada rumpon hidup bervariasi secara spasial (habitat). Secara berurutan kelimpahan hasil tangkapan baronang tertinggi terdapat di habitat muara sungai (MS) sebesar 14,77 ind/ $\mathrm{m}^{2}$, kemudian habitat terumbu karang (TK) sebesar $12,13 \mathrm{ind} / \mathrm{m}^{2}$ dan terakhir habitat padang lamun (PL) sebesar 9,13 ind $/ \mathrm{m}^{2}$. Tingginya kelimpahan juvenil ikan baronang pada rumpon hidup di habitat muara sungai disebabkan karena jenis ikan baronang yang 
Tabel 4 Hasil tangkapan baronang di rumpon berdasarkan habitat

\begin{tabular}{ccccccc}
\hline Habitat & $S(\mathrm{sp})$ & $N\left(\mathrm{ind} / \mathrm{m}^{2}\right)$ & $d$ & $J^{\prime}$ & $H^{\prime}\left(\log _{2}\right)$ & $d$ \\
\hline Muara Sungai (MS) & 5 & 14,77 & 1,48 & 0,78 & 1,26 & 0,35 \\
Padang Lamun (PL) & 5 & 9,13 & 1,80 & 0,55 & 0,89 & 0,58 \\
Terumbu Karang (TK) & 5 & 12,13 & 1,60 & 0,91 & 1,47 & 0,26 \\
\hline Rata-rata & 5 & 12,01 & 1,62 & 0,75 & 1,21 & 0,39 \\
\hline
\end{tabular}

Keterangan: $S=$ jumlah spesies, $N=$ kelimpahan $\left(\mathrm{ind} / \mathrm{m}^{2}\right), \quad J^{\prime}=$ indeks kemerataan Pielou's, $H^{\prime}=$ Indeks Shannon-Wienner, $d=$ indeks Margalef

Tabel 5 Hasil tangkapan baronang hasil tangkapan di rumpon berdasarkan musim

\begin{tabular}{lcccccc}
\hline \multicolumn{1}{c}{ Musim } & $S(\mathrm{sp})$ & $N\left(\mathrm{ind} / \mathrm{m}^{2}\right)$ & $d$ & $J^{\prime}$ & $H^{\prime}\left(\log _{2}\right)$ & $d$ \\
\hline Musim Barat (MB) & 5 & 20,67 & 1,32 & 0,84 & 1,96 & 0,31 \\
Musim Peralihan 2 (MP-2) & 5 & 6,38 & 2,18 & 0,96 & 2,24 & 0,22 \\
Musim Timur (MT) & 5 & 6,44 & 1,15 & 0,61 & 1,42 & 0,52 \\
Musim Peralihan 1 (MP-1) & 4 & 16,00 & 1,08 & 0,56 & 1,14 & 0,54 \\
\hline \multicolumn{1}{c}{ Rata-rata } & 4,75 & 12,37 & 1,43 & 0,74 & 1,69 & 0,40 \\
\hline
\end{tabular}

Keterangan: $S$ = jumlah spesies, $N=$ kelimpahan individu $\left(\mathrm{m}^{2}\right), J^{\prime}=$ indeks kesamaan Pielou's, $H=I n d e k s$ Shannon-Wienner, $d=$ indeks Simpson

dominan ditemukan adalah jenis ikan baronang lingkis (Siganus canaliculatus) dan Siganus javus. (Tabel 4). Dominasi dua jenis baronang tersebut diduga karena muara sungai adalah habitat yang subur. Ikan baronang pada ukuran juwana banyak ditemukan di muara sungai dan bahkan masuk ke tambak-tambak petani, Siganus canaliculatus ditemukan di muara sungai dan padang lamun (Woodland 1990) dan ikan baronang atau Siganidae pada umumnya ditemukan di estuaria, perairan dangkal dan muara sungai (Jalil et al. 2006 ; Gorospe and Demayo 2013). Kemudian kelimpahan ikan terendah di $\mathrm{PL}$, diduga karena jenis ikan yang dominan ditemukan seperti baronang lingkis atau Siganus canaliculatus (Tabel 5) untuk satu kelompok (schooling) dalam jumlah kecil.

Nilai indeks diversitas $\left(H^{\prime} \log _{2}\right)$ hasil tangkapan ikan baronang secara spasial atau habitat antara 0,89-1,26 dengan nilai rata-rata 1,21 . Nilai $H^{\prime}$ hasil tangkapan ikan baronang di tiga habitat berdasarkan nilai indeks ShannonWiennerdan berkorelasi dengan nilai indeks kesamaan Pielou's $(J)$ termasuk indeks keragaman relatif rendah dengan nilai rata-rata 1,21 dan berbanding terbalik dengan indeks dominan $(D)$ Simpson. Nilai indeks diversitas relatif rendah pada tiga habitat dibandingkan dengan hasil penelitian Sugianti dan Mujiyono (2013) dengan nilai $H^{\prime}$ 2,46 dengan berbasis biodiversity ikan karang dan Satrioajie et al. (2012) menemukan indeks diversitas $\left(H^{\prime}\right)$ antara 2,21 2,78 pada keanekaragaman ikan di padang lamun. Indek diversitas relative rendah diduga karena penggunaan rumpon hidup yang luas- annya lebih sempit sehingga peluang ikan untuk hidup di rumpon reltif lebih kecil.

Distribusi spesies ikan yang berasosiasi dengan rumpon secara temporal (musim) menunjukkan jumlah hasil tangkapan yang cenderung sama. Jumlah spesies hasil tangkapan berkisar antara 4 sampai 5 spesies dengan rata-rata 4,75 spesies. Spesies ikan hasil tangkapan terendah ditemukan pada musim peralihan -1 (MP-1), sedangkan tertinggi pada musim barat (MB), musim peralihan-2 (MP-2) dan musim timur (MT) (Tabel 5). Pada tiga musim tersebut spesies ikan baronang hasil tangkapan lebih tinggi, hal ini diduga karena pergerakan arus perairan yang membawa makanan (plankton) lebih padat ke arah pesisir dan suplai makanan dari daratan memalui sungai cukup tinggi. Menurut (Priatna dan Natsir 2007) pada tiga musim arah arus lebih cenderung ke arah pantai yang membawa makanan, sehingga berbagai jenis ikan mengikuti makanan dan berkumpul pada suatu area tertentu sehingga memudahkan untuk penangkapan.

Distribusi kelimpahan hasil tangkapan ikan baronang (ind $/ \mathrm{m}^{2}$ ) bervariasi secara temporal (musim). Kelimpahan hasil tangkapan ikan baronang berkisar antara 6,38 ind $/ \mathrm{m}_{2}$ sampai 20,67 ind $/ \mathrm{m}^{2}$ dengan nilai rata-rata 12,37 ind $/ \mathrm{m}^{2}$. Kelimpahan ikan terendah ditemukan pada musim peralihan-2 (MP-2) sedangkan kelimpahan tertinggi pada bulan Desember atau akhir musim barat (MB) (Tabel 5). Kelimpahan ikan baronang hasil tangkapan pada musim barat lebih tinggi dari musim lainnya, diduga karena pengaruh makanan dan 
pemijahan. Ketersediaan makanan dapat mempercepat ikan lebih cepat dewasa dan memijah sehingga jumlah populasinya lebih besar. Menurut Priatna dan Natsir (2007) bahwa pada bulan Desember (musim barat) kelimpahan ikan hampir dua kali kelimpahan dari musim lainnya karena adanya kelimpahan makanan. Wiyono dan Mahiswara (2013) pada bulan Desember (MB) kondisi perairan Teluk Bone relatif sudah mulai tenang sehingga aktivitas nelayan untuk menangkap ikan juga mulai meningkat. Hasil penelitian Laga et al. (2015) menunjukkan laju penangkapan ikan pepija (Harpadon nehereus) cukup tinggi pada bulan Desember - Januari (akhir MB dan awal MP-2) di Perairan Pulau Tarakan.

Nilai indeks diversitas Shannon-Wienner $(H)$ menunjukkan nilai yang relatif sedang yaitu antara 1,14 sampai 2,24 (Tabel 5), menurut kriteria keanekaragaman Shannon-Wienner nilai indeks keanekaragaman rendah yaitu $\mathrm{H}^{\prime} \leq$ 2,0, sedang yaitu $2,0 \leq H^{\prime} \leq 3,0$ dan indeks keanekaragam tinggi yaitu $H^{\prime} \geq 3,0$. Nilai $H^{\prime}$ hasil tangkapan ikan baronang di empat musim berdasarkan nilai indeks Shannon-Wiennerdan berkorelasi dengan nilai indeks kesamaan Pielou's $(J)$ termasuk indeks keragaman relatif sedang dengan nilai rata-rata 1,69 dan berbanding terbalik dengan indeks dominan $(D)$ Simp- son. Nilai indeks diversitas relatif sedang sama dengan hasil penelitian Isnaini et al. (2014) dengan nilai $H^{\prime} 1,05$ dengan berbasis pada komposisi dan struktur komunitas ikan di muara Musi. Kondisi keanekaragaman 'sedang' hasil tangkapan ikan baronang di rumpon menunjukkan bahwa rumpon hidup sebagai habitat cenderung stabil.

\section{Analisis klaster (cluster analysis)}

Berdasarkan analisis of similaritas (ANOSIM), variasi spasial (stasiun/habitat) dan temporal (musim) hasil tangkapan ikan baronang pada rumpon hidup di perairan pantai Uloulo Kabupaten Luwu (Gambar 4 dan 5).

Hasil tangkapan ikan baronang berdasarkan stasiun atau habitat secara umum terdapat dua variasi kelompok, yakni 1) muara sungai (MS) dengan padang lamun (PL) dan 2) terumbu karang (TK) sebagaimana yang ditunjukkan pada Gambar 4. Hubungan similaritas antara stasiun menunjukkan pola yang sama dengan distribusi spasial hasil analisis parameter diversitas (Tabel 4). Hasil uji statistik (ANOSIM) menunjukkan adanya perbedaan yang sangat nyata kelimpahan ikan hasil tangkapan antar habitat lokasi penempatan rumpon,

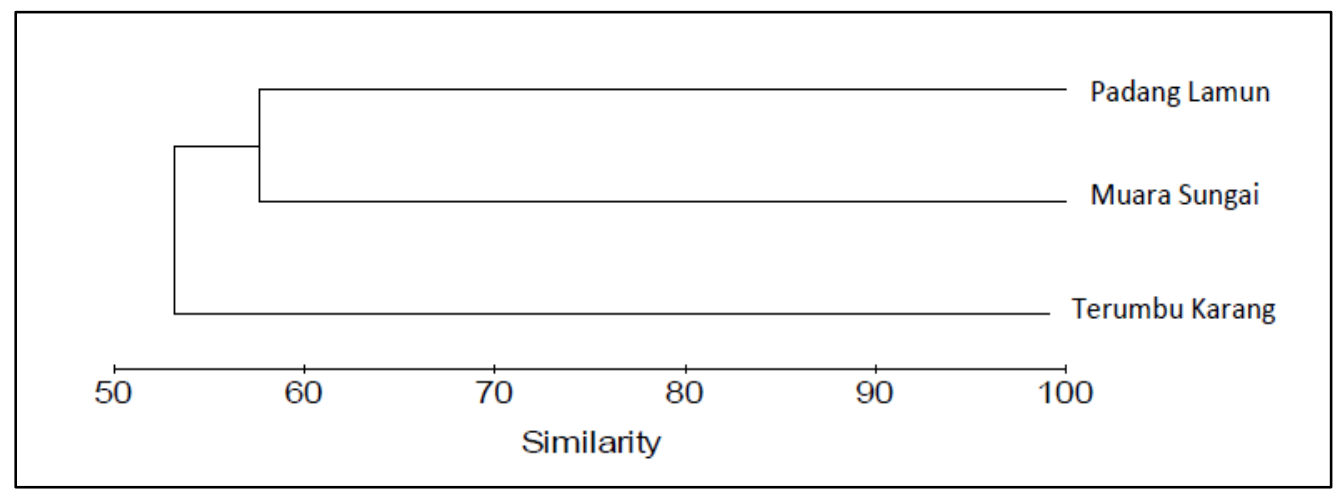

Gambar 4 Dendogram kemiripan kelimpahan hasil tangkapan ikan baronang berdasarkan habitat

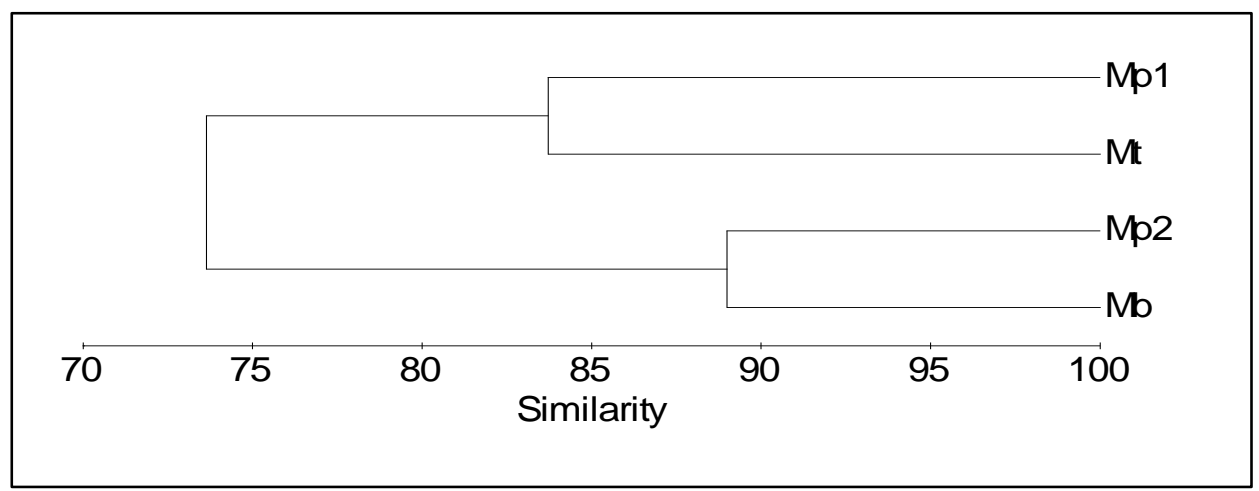

Keterangan: Mp1 : Musim Peralihan-1, Mt : Musim Timur, Mp2: Musim Peralihan-2 dan Mb: Musim Barat

Gambar 5 Dendogram kemiripan kelimpahan hasil tangkapan ikan baronang berdasarkan musim 
dengan nilai (Global $R=0,268$ dan $p=0,001$ ). Hasil uji lanjut menunjukkan habitat MS dan PL berbeda nyata $(R=0,011 ; p=0,028)$ sedangkan habitat MS dan PL berbeda sangat nyata terhadap habitat TK $(R=0,064 ; \mathrm{p}=0,001)$. Kelimpahan hasil tangkapan ikan yang tertinggi pada habitat terumbu karang (TK).

Selanjutnya berdasarkan analisis similaritas, variasi temporal (musim) kelimpahan hasil tangkapan ikan baronang menunjukkan pengelompokkan seperti pada Gambar 5. Secara umum terdapat 2 variasi kelompok kelimpahan hasil tangkapan baronang, yaitu kelompok 1) musim peralihan -1 (MP-1) dan musim timur (MT) dan kelompok 2) musim peralihan-2 (MP2) dan musim barat (MB). Hasil uji statistik (ANOSIM) menunjukkan bahwa kelimpahan ikan antara musim berbeda nyata, dengan nilai (Global $R=0,110$ dan $p=0,001$ ). Kelimpahan ikan hasil tangkapan tertinggi pada musim barat (MB).

Selanjutnya untuk mengetahui karakteristik jenis (spesies) kunci hasil tangkapan ikan baronang pada setiap habitat dan musim maka dilakukan analisis SIMPER (similarity percentage) dengan hasil sebagaimana tertera pada Tabel 6 dan 7. Persentase kontribusi spesies ikan baronang bervariasi berdasarkan habitat. Habitat muara sungai dan padang lamun baronang Siganus canaliculatus berkontribusi cukup tinggi sedangkan pada habitat terumbu karang baronang Siganus virgatus berkontribusi paling tinggi, disajikan pada Tabel 6 . Tingginya persentase kontribusi Siganus canaliculatus di habitat muara sungai dan padang lamun diduga sebagai habitat transit dalam siklus hidupnya sebulum ke terumbu karang sebagai habitat aslinya.

Tabel 6 menunjukkan bahwa hasil tangkapan utama (penciri) ikan baronang pada rumpon yang ditempatkan di habitat padang lamun $(\mathrm{PL})$ yaitu Siganus canaliculatus dengan persentase konstribusi $96,38 \%$. Tingginya persentase Siganus canaliculatus pada rumpon hidup yang ditempatkan (dipasang) di habitat PL diduga karena adanya konstribusi dari habitat padang lamun. Latuconsina et al. (2012) menemukan komposisi jenis Siganus canaliculatus sebesar $62,91 \%$ di habitat padang lamun; Suardi et al. (2016b) menemukan Siganus canaliculatus sebesar $66,42 \%$ di habitat padang lamun. Latuconsina dan Rappe (2013) menemukan baronang lingkis (S. canaliculatus) dominan di habitat padang lamun. Habitat padang lamun yang berfungsi sebagai tempat berlindung, mencari makan dan memijah berbagai jenis dan ukuran ikan turut berpengaruh terhadap tingginya Siganus canaliculatus. Arifin dan Jompa (2005) menemukan kelimpahan juvenil ikan Siganus sp., tertinggi di ekosistem padang lamun dibandingkan dengan ekosistem lainnya. Jaikumar(2012) dan Faisal et al. (2013) rumput laut merupakan makanan utama ikan Siganus sp.

Tabel 6 Karakteristik jenis ikan baronang hasil tangkapan di rumpon berdasarkan habitat

\begin{tabular}{llccc}
\hline No & \multicolumn{1}{c}{ Jenis Ikan } & \multicolumn{3}{c}{ Jenis habitat (persen konstribusi) } \\
\hline & & Muara sungai (MS) & Padang lamun (PL) & Terumbu karang (TK) \\
\cline { 2 - 5 } 1 & Siganus canaliculatus & 57,53 & 96,38 & 25,85 \\
2 & Siganus javus & 36,85 & 2,22 & 0 \\
3 & Siganus guttaus & 1,08 & 1,40 & 0 \\
4 & Siganus virgatus & 0 & 0 & 56,54 \\
5 & Siganus fuscescens & 0 & 0 & 9,54 \\
\hline
\end{tabular}

Tabel 7 Karakteristik jenis ikan baronang hasil tangkapan berdasarkan musim

\begin{tabular}{rlcccc}
\hline & \multicolumn{1}{c}{ Jenis Ikan } & \multicolumn{4}{c}{ Musim (persen konstribusi) } \\
\cline { 2 - 6 } No & $\begin{array}{c}\text { Musim Barat } \\
(\mathrm{MB})\end{array}$ & $\begin{array}{c}\text { Musim } \\
\text { Peralihan-2 } \\
(\text { MP-2) }\end{array}$ & $\begin{array}{c}\text { Musim Timur } \\
(\text { MT) }\end{array}$ & $\begin{array}{c}\text { Musim } \\
\text { Peralihan-1 } \\
\text { (MP-1) }\end{array}$ \\
\cline { 2 - 6 } 1 & Siganus canaliculatus & 53,74 & 38,04 & 95,02 & 75,47 \\
2 & Siganus javus & 19,54 & 43,30 & 0 & 0 \\
3 & Siganus guttaus & 0 & 0 & 0 & 0 \\
4 & Siganus virgatus & 14,97 & 7,72 & 0 & 24,53 \\
5 & Siganus fuscescens & 8,30 & 6,13 & 0 & 0 \\
\hline
\end{tabular}


Konstribusi hasil tangkapan ikan pada habitat terumbu karang (TK) berbeda dengan habitat muara sungai dan padang lamun (Tabel 6). Habitat terumbu karang dicirikan dengan jenis tangkapan utamanya yaitu Siganus virgatus dengan konstribusi sebesar 54,54\%. Besarnya konstribusi $S$. virgatus, di habitat TK diduga karena terumbu karang adalah habitat asli ikan baronang tersebut. Dhahiyat et al. (2003), Manembu et al. (2014), Risamasu dan Ninef (2010) menemukan berbagai jenis ikan karang pada terumbu karang yang ditransplantasi di Pulau Pari termasuk ikan baronang.

Persentase kontribusi spesies ikan baronang bervariasi berdasarkan musim. Ikan baronang jenis Siganus canaliculatus berkontribusi cukup tinggi pada musim timur (MT), musim peralihan-1 (MP-1) dan masim barat (MB) sedangkan pada musim peralihan -2 (MP-2) baronang Siganus javus berkontribusi paling tinggi, disajikan pada analisis SIMPER (Tabel 6). Perbedaan besarnya kontribusi dua spesies baronang tersebut diduga karena perbedaan musim pemijahan.

Tabel 7 menunjukkan bahwa hasil tangkapan utama (penciri) ikan baronang berdasarkan musim adalah baronang jenis Siganus canaliculatus dengan persentase kontribusi sebesar 95,02\%. Tingginya persentase Siganus canaliculatus pada rumpon hidup yang diamati pada musim timur (MT) diduga karena pada bulan April dan Mei (MT) serta Juli dan Agustus (MP-1) adalah musim puncak pemijahan Siganus canaliculatus. Hal ini hampir sama dengan kondisi di Palau (Al-Marzouqi 2013; AlQiswaheet al. 2014). Adapun pada bulan Juli dan Agustus, Siganus canaliculatus di perairan Singapur melakukan pemijahan dalam jumlah kecil (Soh dan Lam 1973; Duray 1998; Huqueet al. 1999). Selanjutnya pada bulan Maret (akhir musim peralihan-2) adalah musim puncak pemijahan Siganus canaliculatus di perairan pesisir Singapur (Soh dan Lam 1973; Duray 1998; Aguset al. 2012).

\section{KESIMPULAN}

Sebaran hasil tangkapan baronang (Siganus sp.) pada rumpon hidup (bio FADs) bervariasi secara spasial (habitat) dan temporal (musim). Hasil penelitian menunjukkan bahwa jumlah spesies ikan baronang yang ditemukan pada kedua rumpon sebanyak 5 spesies dan menyebar pada habitat serta musim yang berbeda. Nilai indeks diversitas Shannon-Wienner $(H)$ pada tiga habitat dan musim relatif sedang. Hasil uji statistik ANOSIM menunjukkan bahwa terdapat variasi kelimpahan hasil tangkapan ikan antar habitat $(R=0,268$; $p=0,001)$. Keti- ga habitat berbeda nyata. Selanjutnya secara temporal atau musim juga berbeda nyata $(R$ $=0,271 ; p=0,001)$. Spesies utama (penciri) baronang yang berkonstribusi besar pada kedua rumpon yang dipasang pada tiga habitat dan empat musim adalah Siganus canaliculatus. Berdasarkan analisis SIMPER menunjukkan bahwa Siganus canaliculatus berkonstribusi sebesar 96,38\% pada habitat padang lamun dan $95.02 \%$ pada musim timur (MT).

\section{SARAN}

Rumpon hidup yang ditempatkan di habitat padang lamun dan dioperasikan pada musim timur perlu dikembangkan jika ingin mengumpulkan benih (juvenil) baronang lingkis (Siganus canaliculatus). Selanjutnya untuk menjaga keberlanjutan ikan baronang lingkis (Siganus canaliculatus) sangat dianjurkan untuk menjaga kelestarian habitat padang lamun.

\section{UCAPAN TERIMA KASIH}

Penulis mengucapkan terima kasih kepada Bapak Menteri Riset dan Dikti yang telah memberikan dana melalui hibah penelitian disertasi doktor (PDD) tahun 2017 sehingga penelitian ini dapat dilaksanakan. Terima kasih pulah kepada bapak Rektor Universitas Andi Djemma yang membantu fasilitas kampus sehingga penelitian ini dapat berjalan sesuai dengan apa yang diharapkan serta mahasiswa perikanan diantaranya Hamsa, Ma'ruf, Ade, dan Irfan Mansur yang membantu dilapangan untuk pengambilan sampel.

\section{DAFTAR PUSTAKA}

Agus SB, Siregar VP, Bengen DB dan Hanggono A. 2012. Profil Batimetri Habitat Pemijahan Ikan Terumbu Hasil Integrasi Data Inderaja Satelit dan Aqustik: Studi Kasus Perairan Sekitar Pulau Panggang, Kepulauan Seribu. Jurnal Teknologi Perikanan dan Kelautan. 2(2): 45-61.

Al Marzouqi A. 2013. Length Based Stock Assessment of the Whitespotted Rabbitfish, Siganus canaliculatus (Park, 1797) from the Arabian Sea off Oman. Thalassas, An International Journal of Marine Sciences. 29(2): 67-76.

Al-Qiswahe MMA, Ali TS, Abahussain AA.2014. Stock Assessment of White Spotted 
Rabbitfish (Siganus canaliculatus Park, 1797) in Jubail Marine Wildlife Sanctuary, Saudi Arabia. International Journal of Fisheries and Aquatic Studies.1(6): 4854.

Arifin dan Jompa J. 2005.Studi Kondisi dan Potensi Ekosistem Padang Lamun Sebagai Daerah Asuhan Biota Laut. Jurnal IImu-IImu Perairan dan Perikanan Indonesia. 12(2): 73-79.

Burhanuddin Al, Budimawan, Sahabuddin (2014). The Rabbit-Fishes (Family Siganidae) From the Coastal Sulawesi, Indonesia. International Journal of Plant, Animal and Environmental Sciences. 4(4): 95-102.

Dempster T. 2003. Biology of Fish Associated With Moored Fish Aggregation Devices (FADs) : Implications for the Development of a FAD Fishery in New South Wales, Australia. ELSEVIER. J. Fisheries Research. 190-201.

Dhahiyat Y, Sinihaji DJ, Hamdani H. 2003. Struktur Komunitas Ikan Karang di Daerah Transplantasi Karang Pulau Pari, Kepulauan Seribu. Jurnal Ikthiologi Indonesia. 3(2): 87-92.

Duray MN. 1998. Biology and Culture of Siganid. Published and Printed by Aquaculture Departement Southeast Asian Fisheries Development Center (SEAFDEC). Tigbauan, Iloilo, Philippines. 60p

Faisal LO, Patadjai RS, Yusnaini. 2013. Pertumbuhan Rumput Laut (Kappaphycus alvarezii) dan Ikan Baronang (Siganus guttatus) yang Dibudidayakan Bersama di Keramba Tancap. FPIK Haluleo. Kendari. J. Mina Laut Indonesia. 1(1): 104-111.

Gorospe JG, Demayo CG. 2013. Population Variability of the Golden Rabbit Fish (Siganus guttatusBloch) (Pisces Siganidae) in Northern Philippinnes. Journal AACL Bioflux. 6(3): 188-201.

Hoque MM, Takamura A, Matsuyama M, Matsuura S, Takano K. 1999. Lunar Spawning in Siganus canaliculatus. J.Fish. Biol. 55: 1213-1222.

Isnaini, Surbakti H, Aryawati R. 2014. Komposisi dan Kelimpahan Fitoplankton di Seki- tar Perairan Pulau Maspari, Ogan Kemerin llir. Journal Maspari. 6(1): 39-45.

Jaikumar, M. 2012. A Review on Biology and Aquaculture Potential of Rabbit Fish in Tamilnadu (Siganus canaliculatus). International Journal of Plant, Animal and Environmental Sciences (IJPAES). Volume (2) Issues(2). 15-24.

Jalii, Mallawa A, Ali SA. 2003. Biologi Populasi Ikan Baronang Lingkis (Siganus canaliculatus) di Perairan Kecamatan Bua Kabupaten Luwu. Jurnal Sains dan Teknologi 3: 8-14.

Krebs CJ. 1989. Ecological methodology (2nd ed). An Imprint of Addision Wesley Longman, Inc. Menlo Park, California. $620 \mathrm{pp}$.

Kune S. 2007. Pertumbuhan Rumput Laut yang Dibudidayakan Bersama Ikan Baronang. Jurnal Agrisistem. 3(1): 34-42.

Laga A, Affandi R, Muchsin I, Kamal MM. 2015. Distribusi Spasial dan Temporal Ikan Pepija, Harpadon Nehereus (Hamilton, 1822) di Perairan Pulau Tarakan, Kalimantan Utara. Jurnal Zoo Indonesia. 24 (1):41-52.

Latuconsina H, Nessa MN, Rappe RA.2012. Komposisi Spesies dan Struktur Komunitas Ikan Padang Lamun di Perairan Tanjung Tiram, Teluk Ambon Dalam. Jurnal IImu dan Teknologi Kelautan Tropis. 4(1): 35-46.

Latuconsina H, Rappe RA. 2013. Variabilitas Harian Komunitas Ikan Padang Lamun. Perairan Tanjung Tiram. Teluk Ambon Dalam. Jurnal Ikhtiologi Indonesia. 13 (1): 35-53.

Manembu I, Afrianto L, Begen D, Yulianda F. 2014. Kelimpahan Ikan Karang pada Kawasan Terumbu Buatan di Perairan Ratatotok Sulawesi Utara. Jurnal Bawal. 6(1): 55-61.

Nevada HAT, Martasuganda S, Zulbainarni N, Dirwana I. 2012. Pengaruh Perbedaan Rumpon terhadap Hasil Tangkapan Juvenil Lobster dengan Korang di Desa Sangrawayan Palabuhanratu. Jurnal Marine Fisheries. 3(2): 135-139. 
Nontji A. 1987. Laut Nusantara. Djambatan. Jakarta. 367p.

Nybakken JW. 1988. Biologi Laut. Suatu Pendekatan Ekologis. Gramedia. Jakarta. $459 \mathrm{p}$.

Odum EP. 1998. Dasar-Dasar Ekologi, Edisi Ketiga (terjemahan Samingan $\mathrm{T}$ \& Srigandono B). (ID): Gadja Mada University Press. $574 \mathrm{p}$.

Priatna A, Natsir M. 2007. Pola Sebaran Ikan pada Musim Barat dan Peralihan. Jurnal Penelitian Perikanan Indonesia. 14(4): 63-72.

Quinn GP, Keough MJ. 2002. Experimental Design and Data Analysis for Biologists. Cambirdge University Press. 537pp.

Risamasu FJL, Ninef JSR. 2010. Analisis Struktur Komunitas Ikan Karang di Rumpon dan Bubu. Jurnal Media Exacta. 10(2): 1 5.

Samples KC, Sproul JT. 1985. Fish Aggregating Devices and Open-Access Commercial Fisheries: A Theoretical Inquiry. Bull. Mar. Sci. (37): 305-317.

Satrioajie WN, Peristiwady T, Pay La. 2012. Keanekaragaman Ikan di Daerah Padang Lamun Kepulauan Banggai, Sulawesi Tengah. Jurnal Bawal. 4(1):9-17.

Sewajo M, Burhanudin S, Djamali, Sianipar P. 1981. Ikan Beronang. Biologi, Potensi dan Pengelolaannya. LON - LIPI. 45p.

Simbolon D, Jeujanan B, Wiyono ES. 2011. Efektifitas Pemanfaatan Rumpon pada Operasi Penangkapan Ikan di Perairan Kei Kecil, Maluku Tenggara. Jurnal Marine Fisheries. 2(1): 19-28.

Soh CL, Lam TJ. 1973.Effect of Photoperiod on Gonadal Maturation in the Rabbitfish,

Siganus canaliculatus Park 1797. Journal Aquaculture. 5(4): 407-410.

Suardi, Wiryawan B, Taurusman AA, Santoso J,Riyanto M. 2016a.Variations in Size and Catch Distribution of White Spotted (Siganus canaliculatus) on Bio-FADs Spatially and Temporary at Luwu Distric, South Sulawesi, Indonesia. Journal $A A C L$ Bioflux. 9(6):1220-1232.

Suardi, Wiryawan B, Taurusman AA, Santoso J,Riyanto M. 2016b. Rumpon Hidup dan Hubungannya dengan Struktur Komunitas Ikan Secara Spasial dan Temporal. Marine Fisheries. Jurnal Teknologi dan Perikanan Laut. 7(1): 83-95.

Subani W. 1986. Telaah Penggunaan Rumpon dan Payos dalam Perikanan Indonesia. Jurnal Penelitian Perikanan Laut. 3(5): 35-45.

Sudradjat A. 2009. Budidaya 23 Komoditas Laut Menguntungkan. Penebar Swadaya. Jakarta. Hal. 171.

Sugianti, Mujiyono. 2013. Biodiversiti Ikan Karang di Perairan Taman Nasional Karimunjawa, Jepara. Jurnal Bawal 5(1): 2331.

Taurusman AA.2011. Pengujian Indikator Ekologis Perikanan Berkelanjutan: Struktur Komunitas Hasil Tangkapan Ikan di Kabupaten Kota Baru, Kalimantan Selatan. Buletin PSP.9(1): 1-12.

Wiyono ES, Mahiswara. 2013. Pengaruh Fase Bulan terhadap Hasil Tangkapan Purse Seine di Bone, Sulawesi Selatan. Buletin PSP. 21(3): 255-262.

Woodland DJ. 1990. Revision of the Family Siganidae with Description on Distribution and Biology. Indo-Pas. Fisher. 136p.

Yusfiandayani. 2010. Perbedaan Bahan Atraktor terhadap Hasil Tangkapan Ikan Pelagis dengan Menggunakan Payang Bugis di Perairan Pasauran, Provinsi Banten. Jurnal Teknologi Perikanan dan Kelautan. 1(1): 47-60.

Yusfiandayani R, Jaya I, Baskoro MS. 2014. Konstruksi dan Produktifitas Rumpon Portable di Perairan Palabuhanratu, Jawa Barat. J. Teknologi Perikanan dan Kelautan. Bekerjasama dengan MSKPI dan FPIK IPB. 5(2): 117-127. 